\title{
Typology of Nurseries and Adoption's level of the Technique of Plants Derived Stem Fragment 'PIF' for the Production of Plantain Planting Material (Musa spp.) in Côte d'Ivoire
}

\author{
KOUA Tano Charles Martin, KONE Tchoa, TOURE Yaya, KONE \\ Mongomake
}

UFR des Sciences de la Nature, Laboratoire de Biologie et amélioration des productions végétales, Université Nangui Abrogoua, ABIDJAN/CÔTE D'IVOIRE

Email: tanocharles1@yahoo.fr

\begin{abstract}
One of the major constraints limiting the development of plantain cultivation is the lack of planting material. In Côte d'Ivoire, to overcome this constraint, the FIRCA (Fond Interprofessionnel pour la Recherche et le Conseil Agricole / Interprofessional Fund for Research and Agricultural Advisory) has organized training workshops on PIF technique (Plants Derived from stem fragment). The objective of this study was to take stock of adoption of the PIF technique for seed production of plantain in Côte d'Ivoire, in order to identify the limits. A survey was carried out in the intervention zones of nurserymen during the periods of October-December 2015 and July-September 2016. The informations collected concern the socio-economic impact of PIF on nurserymen and the level of mastery of the technique by nurserymen. A total of 87 nurserymen were visited. About $75 \%$ of the nurserymen are men and $48 \%$ are over 46 years old. The purchase price of vivoplants fluctuated between 150 and $250 \mathrm{~F}$. CFA. The number of seedlings sold per nurseryman ranged from 6,000 to 180,000 per year. The survival rate in acclimation was at two months between 40 - 85\% and at four months between 35 - 60\%. The average number of vivoplants produced per explant ranged from 1.87 to 17.01. 28.73\% of the nurserymen used suckers of poor quality and $44.82 \%$ of suckers of middle quality. $44.67 \%$ of nurserymen have limited control of the reactivation technique. In Côte d'Ivoire, the nurserymen improved the availability of seeds for plantain producers in the form of vivoplants.
\end{abstract}

Keywords- nurseryman, PIF, Plantain, substrate, vivoplants.

\section{INTRODUCTION}

Plantain is a food plant cultivated for its fruit which is consumed after cooking, in various forms (cooked, boiled, fried, mashed, cake). It is the fourth most important food crop in Côte d'Ivoire after yams, cassava and rice [5]. Rich in carbohydrates, plantain is the equivalent of potatoes in temperate countries [14]. It is also very rich in vitamins (C, B6 and A), potassium, magnesium and several other nutrients [7].

In Côte d'Ivoire, monoculture of plantain is increasingly practiced because of the development of a sub-regional market [1]; [18]. Global production of plantain in 2014 was estimated at more than 34 million tonnes [5]. Côte d'Ivoire has an estimated production of 1.619 million tonnes for a cultivated area of 425000 hectares [5]. However, this quantity remains insufficient, because of an increasing demand and a limited production of plantations. A shortage of plantain fruit is even noted between April and September [4].

To adapt supply to demand, the increase of plantain production and the management of off-season plots are essential. Then it is necessary to have optimal management of technical itineraries, and elite varieties. But, above all, the availability of planting material in quantity and quality. Conventional methods of producing plantain material do not guarantee the production of healthy plants and also do not allow to obtain a high quantity of plants. In addition, the use of vitroplants is a more effective way of controlling the spread of telluric pests. However, the high cost of vitroplants hinders its extension in the small producer [15]; [20]. To overcome this constraint, CARBAP (Centre Africain de Recherches sur Bananiers et Plantains / African Center for Banana and Plantain Research) researchers have developed the technique of PIF (Plants derived from stem fragments) to obtain vivoplants of plantain. This plant material is apparently free from nematodes and weevil larvae [13]; [21]. With PIF technique, it is possible to obtain between 
10 and 100 plants depending on the variety of plantain and the size of the suckers [12]; [16]; [9]. The advantage of the PIF technique lies in the fact that the infrastructures required for its implementation are simple, inexpensive and accessible to all producers. As a result, this technique is experiencing an undeniable boom, especially among Cameroonian producers [16].

In Côte d'Ivoire, several nurserymen of plantain and technicians framing were trained in the technique of PIF with the support of the West Africa Agricultural Productivity Program (PPAAO / WAAPP). The activity of these nurserymen aims to ensure the availability of seeds for plantain producers in the form of vivoplants [24]; [3]; [19].

Since the popularization of the PIF technique as a strategy for mass production of plantain material in Côte d'Ivoire, no available report mentions its level of adoption and especially the constraints encountered by nurs erymen.

Therefore, the general objective of this study is to take stock of adoption of the PIF technique for the production of plantain seeds in Côte d'Ivoire. Specifically, this study will address the social structuring of nurserymen, the socio-economic impact of PIF technique on nurserymen and the level of mastery of the technique by nurserymen. The analysis of the results from survey data will ultimately allow the research to propose solutions that take into account the constraints faced by nurserymen in Côte d'Ivoire in order to improve the production of plantain planting material.

\section{MATERIAL AND METHODS}

2.1. Areas and periods of the study

The study was conducted in all areas of nurserymen establishment, whether or not followed by the FIRCA. The producers of vivoplants applying PIF technique in Côte d'Ivoire are located in the southern, central, eastern and western parts of Côte d'Ivoire, which correspond to forest areas and savannah-forest transition zones (Fig. 1). According to [18], the forest areas receive at least 1300 $\mathrm{mm}$ of rain per year, while the savanna-forest transition zones receive only between 1100 and $1300 \mathrm{~mm}$ per year.

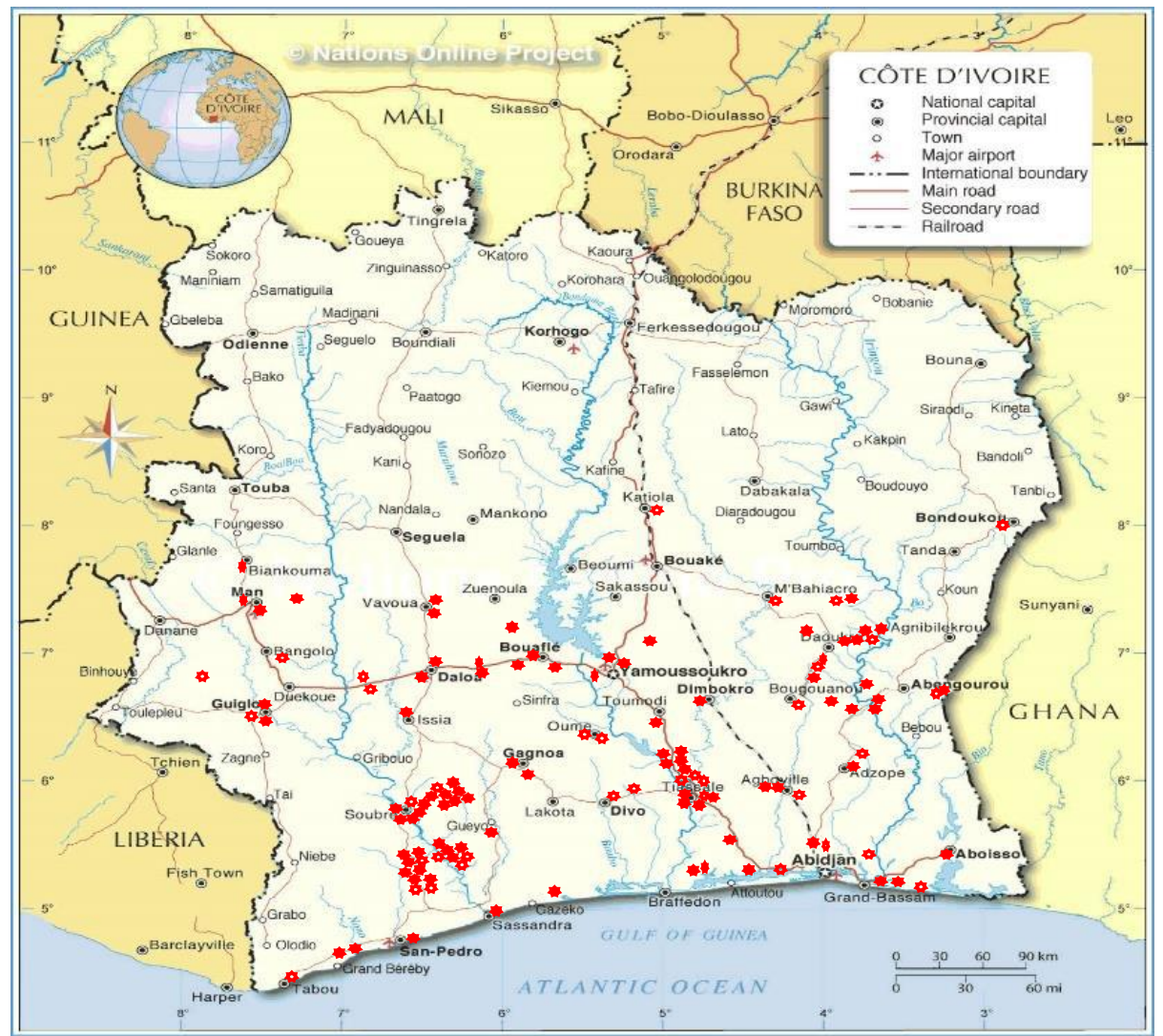

Fig.1: Installation sites (in red points) of plantain nurserymen in Ivory Coast between 2015 and 2016

The execution periods of the study were: (i) October December 2015 and (ii) July-September 2016. These periods correspond respectively to the beginning (2015) and the end (2016) of the vivoplants production campaign by the PIF technique.

\subsection{Plant Material}

To practice PIF, plant material recommended by CARBAP is bayonet suckers. This technique allows maximum expression of the offspring potential of a banana plant and to obtain 10 to 100 plants depending on the plantain variety and the size of the suckers. 


\subsection{Methodologies}

Each nurseryman has been visited at least two times, at the beginning and at the end of the campaign in order to better appreciate the management of the PIF activities. The visits achieve at the beginning of the campaign allow the identification of active and non-active nurserymen. Only active nurserymen were visited at the end of the season.

A survey sheet was designed and provided to the PIF nurserymen. This sheet consisted in three sections (socioeconomic aspect, technical aspect and activity evaluation). The sections "socio-economic aspect" and "technical aspect" were realized by semi-structured interview method. The main lines of the interview are detailed in TABLE 1 . The "activity evaluation" section was performed following semi-structured interview method and direct observations made in the field. Thus, for each visited nurseryman, an assessment was given according to defined qualitative criteria. The different criteria used for the evaluation are summarized in TABLE 2.

Table.1: Survey parameters based on defined sections

\begin{tabular}{|c|c|c|}
\hline Sections & Information on & Survey Topics \\
\hline \multirow{4}{*}{$\begin{array}{l}\text { Socio-economic } \\
\text { aspect }\end{array}$} & The nurseryman & Location ; age range ; sex, level of education \\
\hline & The site & $\begin{array}{c}\text { Number of propagator; number of cultivars; number of } \\
\text { employees ; choice of cultivar }\end{array}$ \\
\hline & The cost of the activity & Cost of inputs; cost of running the site; cost of infrastructure \\
\hline & The profitability of the activity & $\begin{array}{l}\text { Seed transfer price; type of clients; average level of production; } \\
\text { number of plants sold }\end{array}$ \\
\hline \multirow{5}{*}{ Technical aspect } & The seed field & Area; distance between field and site \\
\hline & The origin of the suckers & Description plot of origin of the suckers \\
\hline & The life of the propagators & $\begin{array}{l}\text { Time of half-life of the propagators; number of weaned } \\
\text { seedlings / propagator; number of explants / propagator }\end{array}$ \\
\hline & Acclimation & $\begin{array}{l}\text { Success rate at } 02 \text { months; success rate at } 04 \text { months; } \\
\text { acclimation time }\end{array}$ \\
\hline & Substrate & Substrate state; choice of substrates; formulation of substrates \\
\hline \multirow{3}{*}{$\begin{array}{l}\text { Evaluation of the } \\
\text { activity }\end{array}$} & Quality of the explants & Quality suckers; suckers treatments \\
\hline & Quality of infrastructure & Quality of sawdust; shade quality \\
\hline & Quality of inputs / activities & $\begin{array}{l}\text { (re) seeding propagator; weaning; reactivation; quality of } \\
\text { acclimation substrate; acclimation quality }\end{array}$ \\
\hline
\end{tabular}

Table.2: Criteria and assessments used for the evaluation of the activity of the PIF

\begin{tabular}{|c|c|c|c|c|}
\hline $\begin{array}{l}\text { Appreciation } \\
\text { Parameters } \\
\text { evaluated }\end{array}$ & Very good (+++) & Good (++) & Fair (+) & Bad (-) \\
\hline Quality suckers & $\begin{array}{c}\text { at least } 80 \% \text { of bayonet, } \\
\text { without galleries and } \\
\text { necrosis inside the bulb }\end{array}$ & $\begin{array}{c}60-80 \% \text { of bayonet, } \\
\text { without galleries and } \\
\text { necrosis inside the bulb }\end{array}$ & $\begin{array}{l}40-60 \% \text { of bayonet, } \\
\text { without galleries and } \\
\text { necrosis inside the bulb }\end{array}$ & $\begin{array}{l}\text { less than } 40 \% \text { bayonet, } \\
\text { without galleries and } \\
\text { necrosis inside the bulb }\end{array}$ \\
\hline $\begin{array}{c}\text { suckers } \\
\text { treatments }\end{array}$ & $\begin{array}{l}\text { suckers treated within } \\
24 \text { hours after sampling }\end{array}$ & $\begin{array}{c}\text { suckers treated within } \\
24 \text { to } 72 \text { hours after } \\
\text { sampling }\end{array}$ & $\begin{array}{c}\text { suckers treated within } \\
72 \text { to } 96 \text { hours after } \\
\text { sampling } \\
\end{array}$ & $\begin{array}{l}\text { suckers treated within } \\
96 \text { hours after sampling }\end{array}$ \\
\hline Quality sawdust & $\begin{array}{c}\text { medium grind and } \\
\text { sawdust new }\end{array}$ & $\begin{array}{l}\text { fine grind and sawdust } \\
\text { new }\end{array}$ & $\begin{array}{c}\text { Big grind and sawdust } \\
\text { new }\end{array}$ & $\begin{array}{c}\text { copoh of wood and / or } \\
\text { old sawdust }\end{array}$ \\
\hline Shade quality & $\begin{array}{c}\text { about } 50 \% \text { solar } \\
\text { infiltration, } 30-33{ }^{\circ} \mathrm{C} \\
\text { temperature, relative } \\
\text { humidity over } 85 \%\end{array}$ & $\begin{array}{c}\text { about } 60 \% \text { or } 40 \% \text { solar } \\
\text { infiltration, } 30-33{ }^{\circ} \mathrm{C} \\
\text { temperature, relative } \\
\text { humidity over } 85 \%\end{array}$ & $\begin{array}{l}\text { between } 28-33^{\circ} \mathrm{C} \\
\text { temperature, relative } \\
\text { humidity above } 85 \%\end{array}$ & $\begin{array}{c}\text { temperature below } 28 \\
\text { or above } 34^{\circ} \mathrm{C}, \\
\text { relative humidity below } \\
85 \%\end{array}$ \\
\hline $\begin{array}{l}\text { (Re) seeding } \\
\text { propagator }\end{array}$ & $\begin{array}{c}\text { at least } 80 \% \text { of explants } \\
\text { well placed }\end{array}$ & $\begin{array}{l}\text { between } 80-60 \% \text { of } \\
\text { explants well placed }\end{array}$ & $\begin{array}{l}\text { between } 60-40 \% \text { of } \\
\text { explants well placed }\end{array}$ & $\begin{array}{c}\text { less than } 40 \% \text { of } \\
\text { explants well placed }\end{array}$ \\
\hline
\end{tabular}




\begin{tabular}{|c|c|c|c|c|}
\hline Weaning & $\begin{array}{l}\text { less than } 20 \% \text { of } \\
\text { seedlings without bulb } \\
\text { and / or small }\end{array}$ & $\begin{array}{l}\text { between } 20-40 \% \text { of } \\
\text { seedlings without bulb } \\
\text { and / or small }\end{array}$ & $\begin{array}{l}\text { between } 40-60 \% \text { of } \\
\text { seedlings without bulb } \\
\text { and / or small }\end{array}$ & $\begin{array}{c}\text { more than } 60 \% \text { of } \\
\text { seedlings without bulb } \\
\text { and / or small }\end{array}$ \\
\hline Reactivation & more than $80 \%$ success & $\begin{array}{c}\text { between } 80-60 \% \\
\text { success }\end{array}$ & $\begin{array}{c}\text { between } 60-40 \% \\
\text { success }\end{array}$ & less than $40 \%$ success \\
\hline $\begin{array}{c}\text { quality of } \\
\text { acclimatization } \\
\text { substrate }\end{array}$ & $\begin{array}{l}\text { fully decomposed and } \\
\text { compact }\end{array}$ & $\begin{array}{c}\text { partially decomposed } \\
\text { and compact }\end{array}$ & $\begin{array}{l}\text { poorly decomposed and } \\
\text { compact }\end{array}$ & pasty or friable \\
\hline $\begin{array}{c}\text { Quality } \\
\text { acclimation }\end{array}$ & more than $80 \%$ success & $\begin{array}{c}\text { between } 80 \text { - } 60 \% \\
\text { success }\end{array}$ & $\begin{array}{c}\text { between } 60-40 \% \\
\text { success }\end{array}$ & Less than $40 \%$ success \\
\hline
\end{tabular}

\subsection{Data analysis}

The collected data are registered in the Excel worksheet. They were then grouped together and the various descriptive calculations achieved. The parameters were appreciated and the proportions determined.

For the assessment of suckers and reactivation quality, observations were made on 10 randomly selected suckers in each nursery. Seeding of the explant in propagator was evaluated over an area covering 20 explants. The quality of the acclimation substrate, concerned the appearance (pasty, friable or compact) after watering, when it is strongly pressed in the palm of the hand. As for the quality of acclimatization, the success rate was determined during the propagation under shade at 02 and 4 months after weaning. These parameters were obtained with each nurseryman visited.

The frequencies of citation (FC) of cultivars and substrates, obtained with each nurseryman, are calculated by the following formula:

(FC): NP / NT * 100 with NP: number of times the cultivar / substrate is cited; NT: total number of citations.

\section{RESULTS}

During this survey, 87 out of 107 nurserymen identified were visited. Twenty were not visited as the activities of the PIF were stopped at their site during the investigation period.

3.1. Typology of nurserymen population

Among the nurserymen population, there are 10 groups or associations, 12 women and 65 men. Of the 77 individuals interviewed, $16 \%$ are under 35 years old, $36 \%$ are between 35 and 45 years old and $48 \%$ are over 45 years old (fig. 2). Only $4.37 \%$ of nurserymen have a level of education less than high school.

Of the 87 people interviewed, $85 \%$ received training on PIF as part of the West Africa Agricultural Productivity Program (WAAPP/PPAAO) and $15 \%$ learned the technique on their own. The number of employees per nurseryman ranged from 1 to 8 with an average of 2.10 employed.
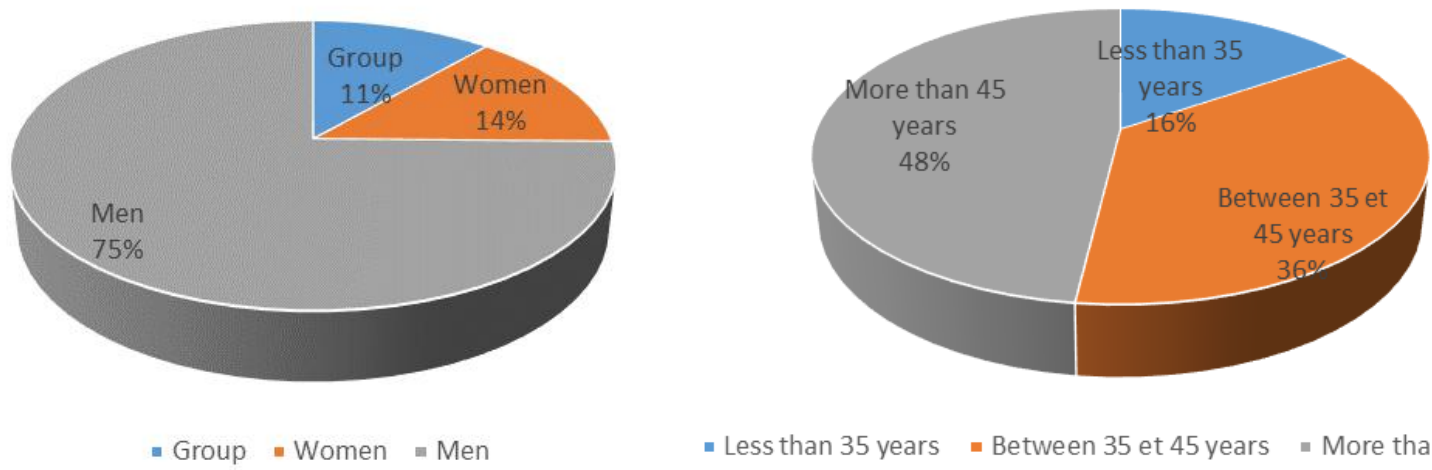

Fig.2: Distribution of nurserymen by sex and age (A: Distribution by sex, B: Distribution by age class)

Out of 87 nurserymen, 33 had seed fields with an average area of 2.63 hectares. The area of the seed fields fluctuated between 0.5 and 10 hectares; the distance between the production site and the point of release was between 0 and 400 kilometers. The most prolific cultivars were " all comers " (FC: 51.9) and Big Ebanga (FC: 32.06). Only 02 nurserymen cultivated FHIA 21 and PITA 3 (FC: 1.53) (fig. 3). The number of cultivars multiplied by nurseryman ranged from 1 to 4 with an average of 1.5 cultivars / nurseryman. 


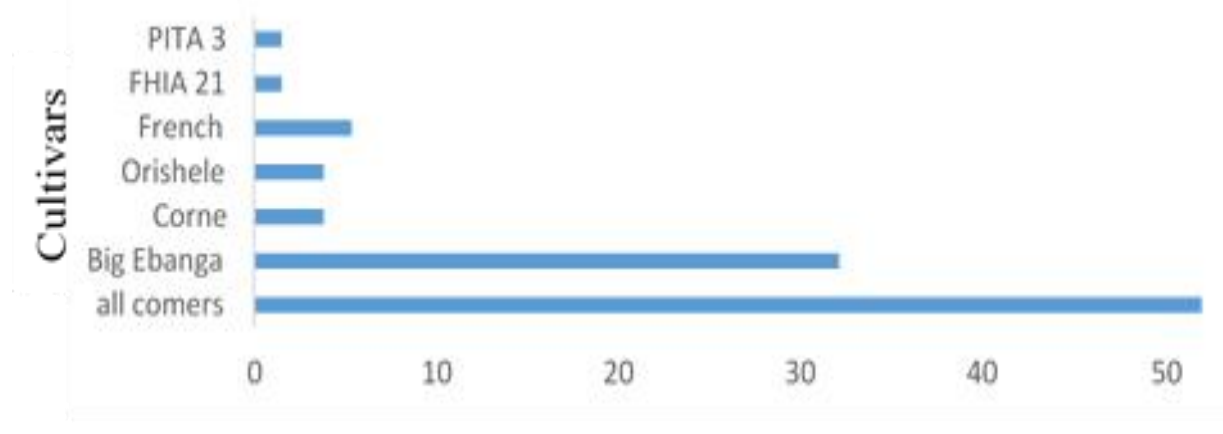

\section{0}

Frequencies of citation

Fig.3: Frequencies of citation of different cultivars

3.2. Economical aspect

The purchase price of the suckers represented in average $42 \%$ of the cost of the inputs. The selling price of vivoplant varied from 150 to $250 \mathrm{~F}$. CFA, but that of the Coffee - Cocoa board was set at 175 CFA francs. During the investigation period, $67 \%$ of the production of vivoplants was purchased by the Coffee-Cocoa Council, $29 \%$ by individuals and $4 \%$ by the producers themselves.

Although production data are not recorded by most nurserymen, $22.99 \%$ found the activity unprofitable, $70.11 \%$ profitable and $6.90 \%$ highly profitable (TABLE 3).

Table.3: PIF economic data's

\begin{tabular}{cccc}
\hline & Minimum & Average & Maximum \\
\hline Number of propagator / nurseryman & 1 & 15 & 100 \\
\hline $\begin{array}{c}\text { Cost per propagator / year of inputs + labor } \\
\text { Number of seedlings produced per } \\
\text { propagator }\end{array}$ & 450.000 F CFA & 265.000 F CFA & 336.000 F CFA \\
\hline Sale price of Vivoplant & 150 F CFA & 2257 & 5000 \\
\hline $\begin{array}{c}\text { Delivery rate of vivoplants / nurseryman } \\
\text { Number of plants delivered / nurseryman }\end{array}$ & $50 \%$ & $72 \%$ & 250 F CFA \\
\hline
\end{tabular}

3.3. Technical as pects of the PIF technique adoption in Côte d'Ivoire

Suckers used by nurserymen come from plots with different levels of maintenance (fig. 4). The plot considered maintained is regularly weeded, leafless and subjected to phytosanitary treatments (fungicides, nematicides, insecticides). Nearly $50 \%$ of nurserymen used suckers from poorly managed (non-irrigated and non-irrigated) plots while $20 \%$ used suckers from plots in very good condition.

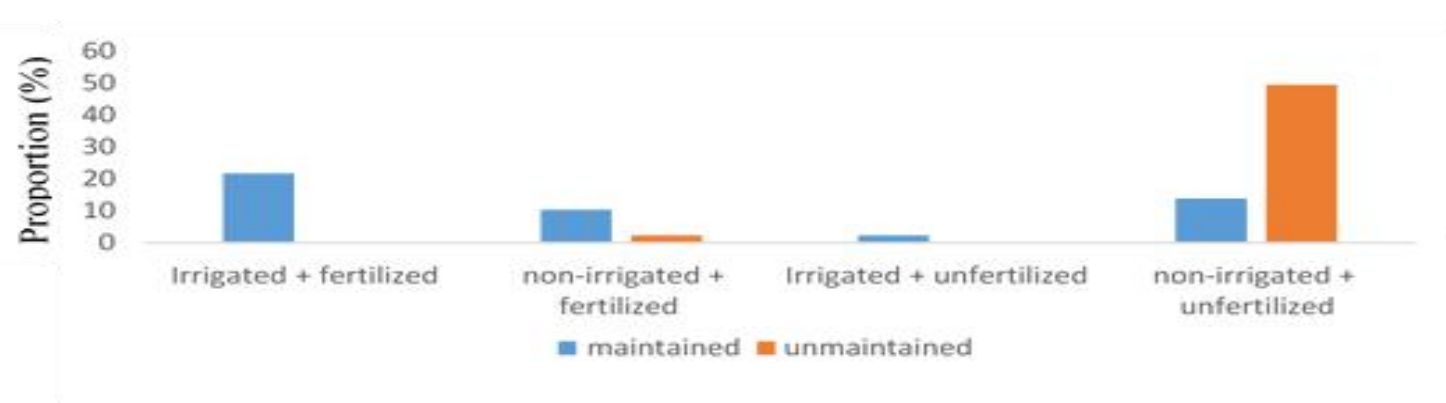

Plot statues

Fig. 4: Proportion of nurserymen according to the state of the suckers sampling plots

The average half-life of the propagator (with at least $50 \%$ of the explants still viable) was 3 months. The average success rate in acclimatization was $61.97 \%$ at 02 months and $49.85 \%$ at 04 months. The level of production is around 6.07 vivoplants per explant put in propagator (TABLE 4).

Of the active nurserymen, $66.66 \%$ used a tunnel for the first phase of plant acclimatization. 


Table.4: Evaluation of some technical parameters of the realization of the PIF
\begin{tabular}{rrrr} 
http://x.doi.org/10.22161/ijeab/4.1.33 & Minimum & Average & Maximum \\
\hline Half-life time of propagators & 2 & 3 & 4 \\
\hline Success rate in acclimation (02 months) & $40 \%$ & $61,97 \%$ & $85 \%$ \\
\hline Success rate in acclimation (04 months) & $35 \%$ & $49,85 \%$ & $60 \%$ \\
\hline Acclimatization time (week) & 05 & 08 & 12 \\
\hline Number of plants produced by explant & 1,87 & 6,07 & 17,01 \\
\hline
\end{tabular}

Many formulations of acclimation substrates are used by nurserymen (fig. 5). These acclimation substrates were formulated in different proportions $(1 ; 3 / 2 ; 1 / 1 ; 1 / 1 / 1)$. The most common substrates are sand + coffee parchment (FC: 49,65034) and sand + sawdust + coffee parchment (FC: 16,08391)

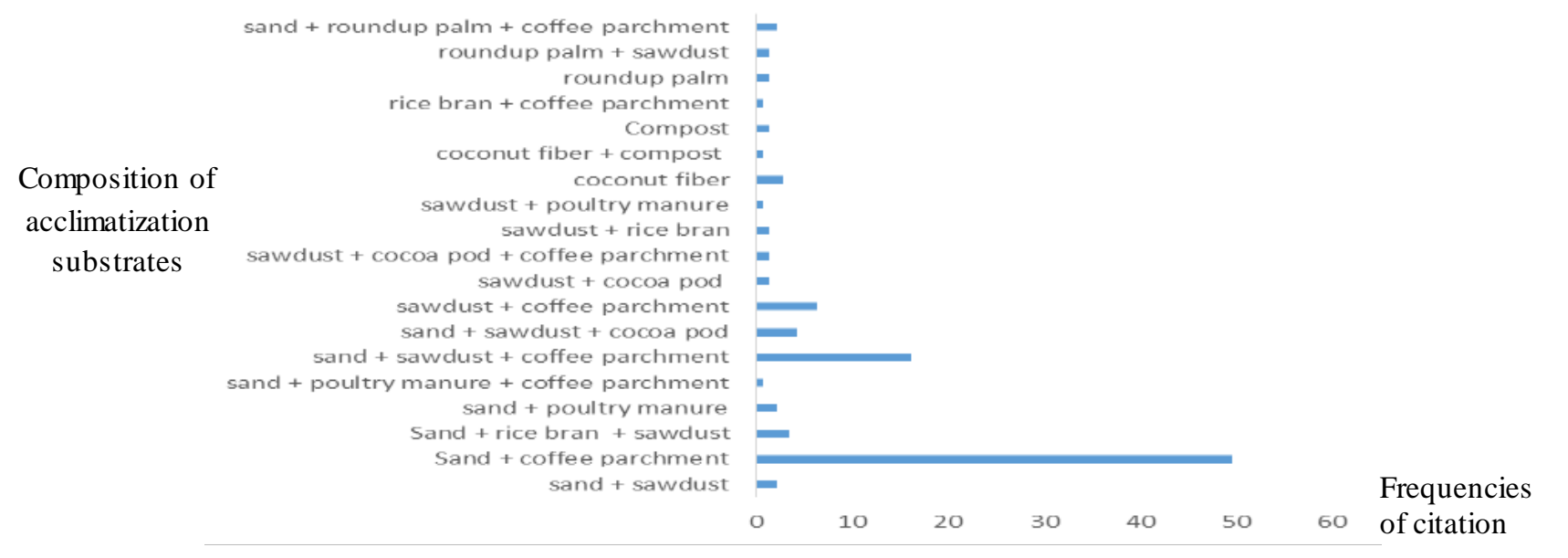

Fig.5: Frequencies of citation (FC) of different types of substrates used during acclimation

3.4. Management of the PIF by nurserymen

The evaluation of the different activities carried out by the nurserymen made it possible to report on the conduct of the PIF.

$28.73 \%$ of nurserymen used suckers judged to be of poor quality and $44.82 \%$, suckers judged to be of average quality. (fig. 6).
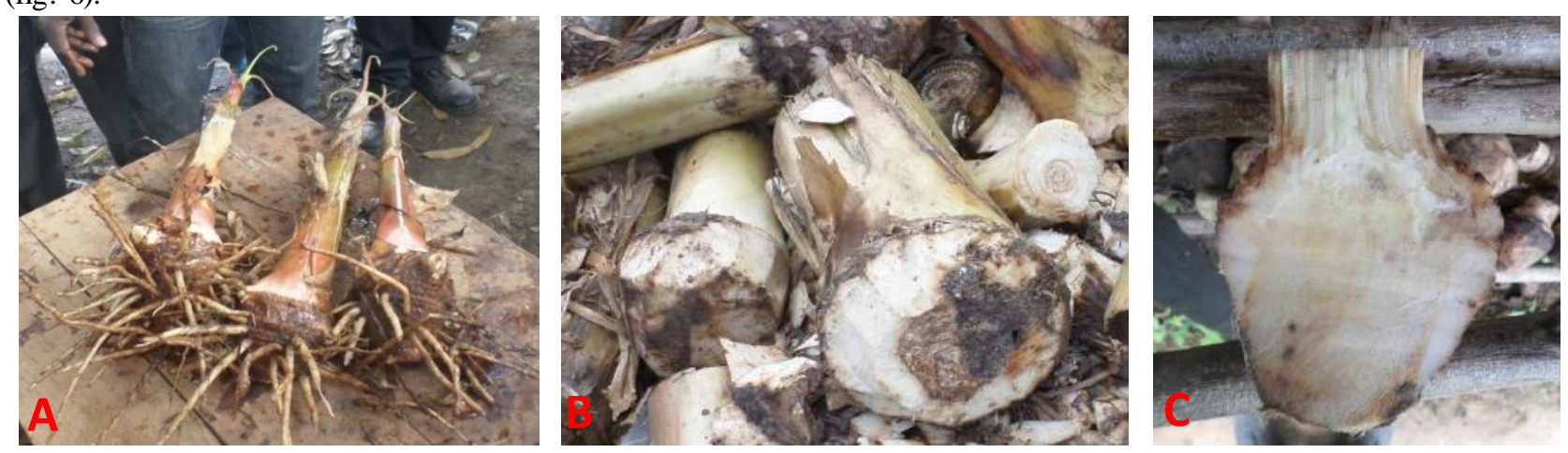

Fig. 6: Different types of suckers used by nurserymen (A: Bayonet suckers of very good quality, B: suckers with a high level of infestation, $C$ : suckers with early necrosis)

Fig. 7 shows the proportions of the different activities carried out by the nurserymen. It also defines the proportions of the modalities of the activities. Thus, many nurserymen have a management of reactivations, acclimatization and suckers considered of average quality. Seeding, weaning, acclimatization, and sawdust generally varied from average to good quality. This resulted in an average proliferation of seedlings of between 2 and 7 seedlings / successful reactivation. 


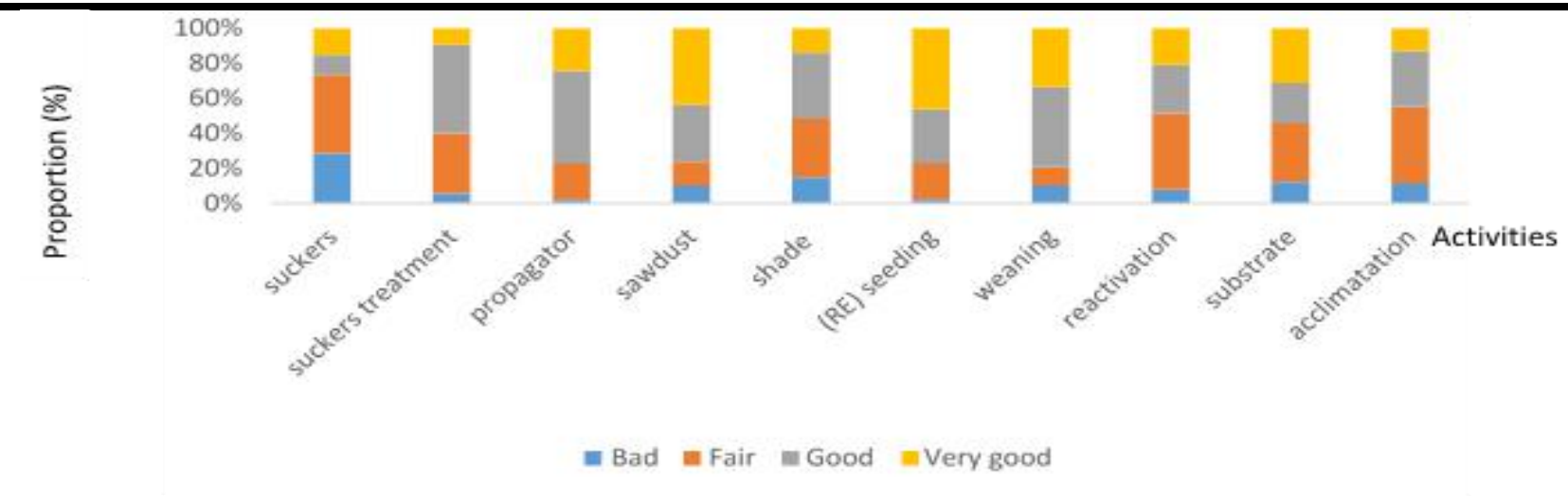

Fig. 7: Proportion of nurserymen according to the modalities of the different activities carried out during the production of vivoplants of plantain.

\section{DISCUSSION}

Socio-economic aspect of the PIF technique adoption in Côte d'Ivoire

PIF is a technology introduced in Côte d'Ivoire by the FIRCA (Interprofessional Fund for Research and Agricultural Council) through WAAPP (West Africa Agricultural Productivity Program). This initiative has greatly contributed to the popularization of this technology. The strong demand of the cocoa sector, in plantain, as part of the replanting of the orchard will contributed to develop a market, thus allowing the development of the vivoplant plantain production line. Also, monoculture of plantain is growing up in Côte d'Ivoire [1], increasing the need for vivoplants.

The survey revealed that PIF technique is practiced in all forest areas of Côte d'Ivoire. The location of nurserymen is due to the fact that these areas are the main growing areas for plantain in Côte d'Ivoire [18]; [22]. Indeed, [18] has shown that plantain is grown in all forest areas and, to a lesser extent, in savannah-forest transition areas.

The PIF is practiced mainly by men and the proportion of young people is low. The acquisition of suckers and the management of labor entail a significant expense for nurserymen. This would limit its adoption by women and youth who have limited economic resources.

The majority of nurserymen use "all-comers" (unidentified cultivar and at handy, that is to say consisting of several cultivars), "Big Ebanga", "Horn", "Orishele" and "French (Agninin)" for the production of vivoplants. A small proportion uses the introduced hybrids "FHIA 21" and "PITA 3". These choices are variously justified. The use of "all-comers" would be due to the high demand for seedlings (cocoa board and some plantain producers) and the non-requirement of farmers. These factors would have led nurserymen to base their choice on the availability of suckers, on cultivars strongly appreciated by the populations, resistant and / or high yielding (monoculture of banana). Thus, "all-comers" would be used by nurserymen who do not have a seed field or have small plots of seed fields that fail to meet the need for suckers. The cultivar "Big Ebanga", present at the majority of the nurserymen was distributed by the FIRCA for the creation of their seed field. The cultivars "Horn", "Orishele" and "French (Agninin)" are popular enough, while "FHIA 21" and "PITA 3" have been poorly appreciated.

The majority of nurserymen have found that the planting material production activity using PIF is profitable. The profitability of the activity would be closely linked to the yield (number of plants produced / explants) which varies greatly from one nurserymen to another, depending on the quality of the inputs and the different operations of the PIF. Indeed, many authors [6]; [17]; [2]; [10] report that this technique allows to consider yields of 10 to 100 seedlings per sucker. For example, nurserymen who produce less than 10 seedlings per sucker estimate that the PIF is very unprofitable, and those who have a lot more consider it very profitable.

Technical aspects of the adoption of PIF technique in Côte d'Ivoire

One of the problems facing nurserymen is the absence / insufficiency of seed fields. The number of seedlings produced is linked to the quality of the suckers used. Nearly half of the suckers used come from nonmaintained, non-irrigated and unfertilized plots. Suckers obtained on these plots have poor sanitary quality. The poor quality of the suckers is explained by the use of a high quantity of non-bayonet suckers (strains, small suckers), and also of the suckers with numerous galleries and / or necrosis in the bulb. In addition, the suckers are often transported over long distances (up to $400 \mathrm{~km}$ from the site). These factors explain the low level of productivity of nurserymen, compared to the potential of the PIF. Indeed, most nurserymen do not have a seed field and for those who own, the exploited area cannot cover 
their need for suckers. They therefore resort to peasant plots to obtain suckers. An investigation conducted by [23] indicates that farmers provide very little care for plantain and their knowledge of pests is limited. The work of [13] and [9] indicate that the physiological state of suckers can influence productivity. [13] found that low production rates of "Kelong mekuitou" and "French clair" cultivars are attributed to a defective starting material condition (suckers attacks by weevils), which would have limited their physiological potential. As for [9], they have shown that the size and physiological state of suckers (under the influence of apical dominance and / or dehydrated for a certain time) strongly influence the number of vivoplants produced.

The level of success of the reactivations is fair. Which could suppose insufficiencies in the conduct of the reactivations. Indeed, the health status of the explant, the type of plantlets reactivated (size and position) and the total number of reactivation on an explant could influence the proliferation of seedlings on the explant. However, according to [13], each suckers on the stem of a banana tree would be at a stage of morphogenetic development and physiological functioning that would confer its own abilities. These gains would therefore occur in the slow or rapid expression of seeded explants. This means that the position of the suckers on the mother foot would influence the response to reactivation. A similar suggestion was also made by [8]. According to this author, the reactivity of the explant is linked to its position on the parent strain, which exerts a more or less strong apical dominance.

During acclimatization, nurserymen face many constraints that are usually adequate shading and the availability of a good quality acclimation substrate. Nurserymen often fail to ensure good temperature management under the shade, due in part to the scarcity of palms in many areas of production. It is also difficult for them to have well decomposed organic substrates in sufficient quantity. Nurserymen choose the substrate according to its availability and / or cost in the area. For example, some nurserymen use several substrate formulations in a single year. This substrate diversity has led to variability in the rate of plant loss during acclimation. In addition, during the survey, many weaned plants were found to be small in diameter and very slender. The works reported by [11] and by [5] showed that plant survival and development during acclimation of plantain vivoplants are influenced by exogenous factors (microclimate around plants and the state of substrate decomposition) and endogenous (diameter of weaned plants). In addition, it was found that a high proportion of plants were lost post-acclimation (04 months after weaning), in the period between the end of acclimation and the removal of plants. The observed loss is explained by the competition for the light between seedlings in nurserymen which becomes more important after $03-04$ months. This would cause a gradual etiolation of many plants that eventually die.

\section{v. CONCLUSION}

In total, this study has shown that PIF activity is widespread in all plantain production areas in Côte d'Ivoire. A large part of the plants produced is used for the banana - cocoa association. The activity of the PIF is a significant source of income for nurserymen. However, the vivoplants market is closely linked to the need for cocoa council in vivoplants.

The nurserymen have a good command of the technical itinerary of the PIF but have difficulties in obtaining quality inputs (suckers, palms). The poor sanitary status of the initial suckers, an average success level of the reactivations and the losses of the plants in acclimation and post acclimation explain the low yield of the explants compared to the estimated yields of the PIF.

Thus, an improvement in the sanitary quality of the available suckers, an optimization of the reactivation behavior and a better technique of conservation of the plants in acclimation could strongly improve the productivity of the nurserymen.

\section{ACKNOWLEDGEMENT}

This survey was carried out thanks to the technical and logistic support of the Cabinet ELITE AGRO CONSULTING which was in charge of the management of nurserymen of the PIF trained by the FIRCA.

\section{REFERENCES}

[1] Adiko A. (2000). Synthèse des activités de recherche sur les bananiers et plantains en Côte d'Ivoire en 1998-1999 et perspectives. In : Akyeampong E. (Ed.). Musa Network for West and Central Africa (MUSACO), Report of the third Steering Committee Meeting help in Abidjan (Côte d'Ivoire) 23-24 novembre 1999. DOUALA (Cameroun): INIBAP, 15-16.

[2] Amoa A. J. (2017). Optimisation de la productivité de vivvoplants de bananier plantain par ingenierie biologique. Thèse de doctorat de l'Ecole Doctorale Polytechnique de l'INPHB, Yamoussoukro - Côte d'ivoire, $152 \mathrm{p}$.

[3] CARBAP. (2014). Retrieved from http://www.carbapafrica.org/index.php/component/co ntent/article/17-actualites/85-atelier-de-reflexionssur-la-mise-en-place-d-un-plan-de-publication-desresultats-scientifiques-du-projet-coraf-plantain, viewed on $18 / 10 / 2016$ ) 
[4] CNRA. (2005). Bien cultiver la banane plantain en Côte d'Ivoire, Direction des programmes de recherche et de l'appui au développement du Centre Nationnal de Recherche Agronomique, $4 \mathrm{p}$.

[5] FAOSTAT. (2017). Retrieved from http://www.fao.org/faostat/en/\#data/QC, viewed on 25/09/2018

[6] Fotso B. (2016). Evaluation de l'efficacité de souches endogènes de champignons mycorhiziens à arbuscules dans la résistance du bananier plantain (Musa sp., Musaceae) au stress hydrique en Côte d'Ivoire. Thèse de doctorat de l'Ecole Doctorale Polytechnique de l'INPHB, Yamoussoukro - Côte d'ivoire, $179 \mathrm{p}$.

[7] Jones D.R. (2000). Diseases of Banana, Abaca and Enset, CABI Publishing, CAB International, Royaume-Uni, 544 p.

[8] Koné T. (2014). Optimisation de la production de matériel végétal sous forme de semences chez trois cultivars (Orishele, Corne 1 et French 2) de bananiers plantain [Musa spp., AAB (Musaceae)] cultivés en Côte d'Ivoire. Thèse de Doctorat de l'Université Nangui Abrogoua, Abidjan, Côte d'Ivoire, 163 p.

[9] Koné T., Soumahoro B.A., Coulibaly K.Z., Traore S., Koné D., Koné M. (2016). Effects of substrates, weight and physiological stage of suckers on massive propagation of plantain (Musa paradisiaca L.), International Journal of Research, 4, (1): 1-13

[10] Koné T., Koua T.C.M., Doumbouya M., Traoré S., Kouakou H.T., Dogbo O.D., Koné M. (2017). Effets du durcissement et des substrats sur la croissance des vivoplants de bananier plantain du cultivar "corne" (Musa $x$ paradisiaca L., Aab) en phase d'acclimatation. REB PASRES, 2(3) : 7-20.

[11] Koua T.C.M. (2014). Effets de différents types de substrats sur la croissance des vivoplants de bananiers plantain (Musa sp.) en phase d'acclimatation. Mémoire de master de biologie et protection des végétaux, Université Nangui Abrogoua, Abidjan-Côte d'Ivoire, 57p.

[12] Kwa M. (2000). La technique des plants issus de fragments de tige (PIF). Techniques horticoles de production de masse de plants de bananiers. (CRBP, Douala, Cameroun). Fiche technique, 4p.

[13] Kwa M. (2003). Activation de bourgeons latents et utilisation de fragments de tige du bananier pour la propagation en masse de plants en conditions horticoles in vivo. Fruits, 58 (6): 315-328.

[14] Lescot T. (2000). Banane : Production, commerce et variétés, Fruitrop, $75: 2-3$

[15] Molina A.M.E. (1987). Sistema de propagación rápida de banano (Musa $\mathrm{AAB}$ ). Método alterno entre el convencional y el cultivo de tejidos. Revista de la Asociación Bananera Nacional (ASBANA).

[16] N'go-samnick E. L. (2011). Production améliorée de la banana plantain. 24p. http://publications.cta.int/media/publications/downlo ads/1650_PDF.pdf, consulté le 22 Octobre 2016

[17] Ongagna A., Mialoundama F., Bakouetila M.G.F. (2016). Etude de la production des plants de bananiers et plantains (Musa spp.) par la technique des PIF au Congo: Effets des substrats sur la croissance et le développement des plants en pépinière. International Journal of Neglected and Underutilized Species 2: 42-56.

[18] Perrin A. (2015). Etude de la filière Banane Plantain en Côte d'Ivoire, Rongead, 66p. Retrieved from https :/www.alimenterre.org/etude-de-la-filiere-

banane-plantain-en-cote-d-ivoire, viewed on 22/09/2018

[19] PPAAO. (2014). Note conceptuelle PPAAO (Programme de Productivité Agricole en Afrique de l'Ouest), Formation des acteurs nationaux et sous régionaux a la maitrise de la technique de production de plants de bananier plantain par la technique des plants is sus de fragments de tige (pif), 4p.

[20] Rao P.S.G., Suprasanna P., Bapat V.A. (1993). Encapsulation de méristèmes apicaux de bananiers : un nouveau système de propagation et de distribution-InfoMusa, 2 (2): 4-5.

[21] Tenkouano A., Hauser S., Coyne D., Coulibaly O. (2006). Clean planting materials and management practices for sustained production of banana and plantain in Africa. Chronica Horticulturae, 46 : 1418.

[22] Thiémélé D.E.F., Traoré S., Aby N., Gnonhouri P., Yao N., Kobenan K., Konan E., Adiko A., Zakra N.J. (2017). Diversité et sélection participative de variétés locales productives de banane plantain de Côte d'Ivoire. Journal of Applied Biosciences 114: 1132411335

[23] Traore S., Kobenan K., Kouassi K.S., Gnonhouri G. (2009). Systèmes de culture du bananier plantain et méthodes de lutte contre les parasites et ravageurs en milieu paysan en Côte d'Ivoire. Journal of Applied Biosciences 19: 1094 - 1101.

[24] WAAPP. (2013). WAAPP INFO Côte d'Ivoire, Bulletin d'informations du PPAAO / WAAPP Côte d'Ivoire (Programme de Productivité Agricole en Afrique de l'Ouest/ West Africa Agricultural Productivity Program) - No 78 p. 